\title{
Evaluation of Patients Who were Referred to Our Outpatient Clinic with Suspicious Sexual Contact
}

\author{
Dilek YEKENKURUL
}

\begin{abstract}
Aim: Sexually transmitted infections are preventable, common diseases with serious complications and high morbidity. Patients with suspicious sexual contact in Turkish society, find it difficult to consult a physician due to public pressure. Patients with suspicious sexual contact who applied to the Infectious Diseases and Clinical Microbiology outpatient clinic were analyzed.

Material and Methods: Patients (62 patients) over the age of 18, who applied to Infectious Diseases and Clinical Microbiology outpatient clinic with suspicious sexual contact, between March 2018-January 2019, were included in the study. The demographic characteristics of the patients such as age, gender, marital status; also complaints, using of condom, physical examination findings, and all examinations during the six-month follow-up were recorded.

Results: In this study, $56(90 \%)$ male and $6(10 \%)$ female patients with a mean age of $33.40 \pm 14.11$ years were included. High percentage $(58 ; 93 \%)$ of patients didn't use condoms during sexual contact, $21(34 \%)$ of the patients had more than one partner, the most common diagnosis was urethritis $(21 ; 34 \%)$, one patient in a bisexual relationship was diagnosed with acute HIV infection, and was observed that the diagnosis of syphilis $(9 ; 15 \%)$ was quite high.

Conclusion: Results such as the low rate of use of condoms made us think that there is a lack of knowledge about sexually transmitted diseases in the society. Considering the possibility of increasing infection rates in the coming years; we think that the necessary importance should be given to sexually transmitted diseases and frequent public trainings should be provided.
\end{abstract}

Keywords: Sexually transmitted diseases; suspicious sexual contact; condom.

\section{Şüpheli Cinsel Temas ile Polikliniğimize Başvuran Hastaların Değerlendirilmesi}

\section{ÖZ}

Amaç: Cinsel yolla bulaşan enfeksiyonlar önlenebilir, ciddi komplikasyonları ve yüksek morbiditesi olan yaygın hastalıklardır. Türk toplumunda şüpheli cinsel temasta bulunan hastalar, toplum baskısı nedeniyle bir hekime başvurmakta zorlanmaktadırlar. Enfeksiyon Hastalıkları ve Klinik Mikrobiyoloji polikliniğine başvuran şüpheli cinsel temaslı hastalar incelenmiştir.

Gereç ve Yöntemler: Mart 2018 ve Ocak 2019 tarihleri arasında şüpheli cinsel temas öyküsü ile Enfeksiyon Hastalıkları ve Klinik Mikrobiyoloji polikliniğine başvuran, 18 yaş üstü olan, 62 hasta çalışmaya dahil edildi. Hastaların yaş, cinsiyet, medeni durum gibi demografik özellikleri; ayrıca şikayetleri, kondom kullanımı, fizik muayene bulguları ve altı aylık takipteki tüm fizik muayene bulguları kaydedildi.

Bulgular: Bu çalışmaya; yaş ortalaması 33,40 $\pm 14,11$ yıl olan, 56 (\% 90) erkek ve 6 (\% 10) kadın hasta alındı. Yüksek oranda hasta $(58 ; 93 \%)$ cinsel temas sırasında kondom kullanmamıştı; hastaların 21'inin (\% 34) birden fazla partneri vard1; en sık tanı üretritti (21; \%34); biseksüel ilişkisi olan bir hastaya akut HIV enfeksiyonu tanısı konuldu ve sifiliz tanısının oldukça yüksek olduğu görüldü $(9 ; \% 15)$.

Sonuç: Kondom kullanım oranının düşük olması, toplumda cinsel yolla bulaşan hastalıklar hakkında bilgi eksikliği olduğunu bize düşündürdü. Önümüzdeki yıllarda enfeksiyon oranlarının artma olasılığı göz önüne alındığında; cinsel yolla bulaşan hastalıklara gerekli önemin verilmesi ve sık sık halk eğitimlerinin yapılması gerektiğini düşünüyoruz.

Anahtar Kelimeler: Cinsel yolla bulaşan hastalıklar; şüpheli cinsel temas; kondom. 


\section{INTRODUCTION}

Sexually transmitted diseases (STDs) are common and important public health diseases that cause serious complications if not treated, and require rapid diagnosis and treatment (1). According to the data of the World Health Organization (WHO), more than 448 million curable and newly diagnosed STDs cases are seen worldwide (2). In the European region, including our country, it is estimated that 46.8 million of 450 million people aged 15-49 have STDs (3).

In this group of diseases, which are caused by different fungi, bacteria, parasites and viruses, the main route of transmission is unprotected sexual contact. In addition, it can be transmitted to the baby during pregnancy, and can be transmitted by transfusion or contact of blood and blood products (4). STDs can cause viral infections such as HIV, hepatitis B, hepatitis $C$ that cause systemic and chronic infections in patients, and also cause HPVinduced genital cancers. Apart from these, they can also cause cervicitis, urethritis, vaginitis, epididymitis, prostatitis, genital wart and genital ulcer $(4,5)$. Unlike these infections, they may cause complications such as chronic pelvic pain, ectopic pregnancy, and infertility (6). Patients with suspicious sexual contact in Turkish society find it difficult to apply to a hospital or family doctor due to public pressure. Generally, they wait for their complaints to resolve spontaneously, and causing further delay in diagnosis. Due to this reason, they do not apply to their family physician and seek to find a physician (7). They frequently apply to departments such as Infectious Diseases and Clinical Microbiology, Urology, Gynecology and Obstetrics, Dermatology and Venereal Diseases. In Duzce Atatürk State Hospital, which is a second step state hospital, such patients with suspicious sexual contact most frequently apply to our Infectious Diseases department. Due to the limited number of studies on STDs, this implicit disease group, it was aimed to examine patients with suspicious sexual contact who applied to the our Infectious Diseases and Clinical Microbiology outpatient clinic.

\section{MATERIAL AND METHODS}

After obtaining the approval of the ethics committee from Duzce University Faculty of Medicine (01.04.20192019/81) and the approval of the chief physician of the hospital; the patients who applied to Duzce Atatürk State Hospital Infectious Diseases and Clinical Microbiology outpatient clinic between March 2018 and January 2019 were examined. Having sexual intercourse with a partner whom the patient did not know before was defined as suspicious sexual contact. A total of 62 patients over the age of 18 who had suspicious sexual contact in the last one year were included in the study.

Due to the different incubation times of each disease and the long incubation periods of diseases such as HBV, HCV, HIV, patients who apply with suspicious sexual contact are followed up for at least six months, in our polyclinic. They are called for controls first weekly and then monthly. All findings are recorded in the patient file and hospital database. All recorded data of 62 patients were accessed retrospectively.

For the study, demographic characteristics of the patients such as age, gender, marital status; using of condom during sexual intercourse, complaints, physical examination findings, number of days after sexual contact, number of sexual partners, first unit applied, chronic disease history, new diagnosis and treatment were recorded. Venereal Disease Research Laboratory (VDRL), Treponema Pallidum Hemagglutination (TPHA), HBsAg, Anti-HBs, Anti HBcIGg, Anti-HCV, Anti-HIV, Herpes Simplex Virus (HSV) IgM and HSV IgG, white blood cell, ALT, AST, C-reactive protein (CRP), sedimentation, complete urine test, urine culture, urethral discharge culture results were retrospectively investigated from the existing hospital database and files. Although some patients have findings such as urethral discharge, dysuria, redness around the urethra, pyuria in the complete urinalysis; urine culture was negative. These patients were diagnosed with urethritis, and a response was obtained to antibiotics used in the diagnosis of urethritis such as doxycycline and ciprofloxacin. Prostatitis was considered in the prostate examination of some patients with prolonged discharge and dysuria, due to increased temperature and sensitivity in the prostate. Tinea cruris, HPV and HSV infection were diagnosed by physical examination. In addition, all of them response to valganciclovir, and two of them were Herpes Simplex Virus (HSV) IgM positive. But, distinction could not make between primary, nonprimary or recurrent HSV infection. HIV infection was diagnosed with positive anti-HIV Western Blot confirmation test result. Syphilis was diagnosed by positive TPHA, VDRL together and physical examination.

\section{RESULTS}

With an average age of $33.40 \pm 14.11$ years, between the ages of $18-75$; a total of 62 patients, $56(90 \%)$ male, 6 (10\%) female, were included to the study. 43 (69\%) of the patients were single and $19(31 \%)$ were married. When partner relationships were examined, it was observed that $19(31 \%)$ patients had sexual contact with a sex worker and a total of $21(34 \%)$ had more than one partner. It was noteworthy that only four (7\%) patients used condom during sexual contact. A male patient had bisexual relationship; the other 61 patients were heterosexual. $33(53 \%)$ of 62 patients applied to our outpatient clinic, in the first month after sexual contact. The mean admission time was $17.48 \pm 9.78$ days in patients who applied in the first month, and $69.64 \pm 88.99$ days in all patients (Table 1).

While the first admission clinic of 40 (64\%) patients was the Infectious Diseases and Clinical Microbiology outpatient clinic; 14 (23\%) were patients referred from Urology, five (8\%) from Family Physician, three from Dermatology outpatient clinic. 14 patients had at least one chronic disease; two of them had chronic hepatitis B and one had cervical cancer due to human papilloma virus.

In the complaint information recorded, 29 (47\%) patients had different complaints, while $33(53 \%)$ patients did not have any complaints; they came only for precautionary purposes. Some patients presented with the complaint of urethral discharge, but no discharge was observed during the examination. Therefore, urethral discharge culture could not be sent from these patients to the laboratory for the test. Even so, the most common examination finding 
was discharge or redness around the urethra (14 patients, 23\%). After six months of follow-up, 28 patients were not diagnosed with any STDs; the most common diagnosis among the other 34 patients (21 patients, 34\%) was urethritis. One male patient was admitted with genital wart occured after suspicious sexual contact, and HPV infection was considered. One 28-years-old male patient who had bisexual relationship was diagnosed with acute HIV infection (Table 2).

Table 1. Patients' chronic diseases, demographic and relationship feature

\begin{tabular}{|l|c|}
\hline Characteristics & Results \\
\hline Average age & $33.40 \pm 14.11$ years \\
Time to apply to the & $69.64 \pm 88.99$ days \\
Molyclinic Gender & $56(\% 90)$ \\
Female & $6(\% 10)$ \\
Marital status & \\
Single & $43(\% 69)$ \\
Married & $19(\% 31)$ \\
Number of partners & $41(\% 66)$ \\
One & $12(\% 19)$ \\
Two & $9(\% 15)$ \\
More than two & \\
Using condom & $58(\% 93)$ \\
No & $4(\% 7)$ \\
Yes & \\
Chronic disease & $48(\% 77.5)$ \\
No & $2(\% 3)$ \\
Chronic hepatitis B & $1(\% 1,5)$ \\
HPV & \\
Others & \\
\hline
\end{tabular}

HPV: Human papilloma virus

*Others:Depression, hypertension, diabetes mellitus, coronary

artery disease, goiter, benign prostatic hypertrophy, asthma

The anti-HIV result of the patient, who previously stated that he did not have such a disease, was studied three times. When all three were positive, Western Blot confirmation test was performed, and Western Blot result was positive, too. Next, HIV RNA resulted in 31700 copies / mL. Since CD4 could not be studied in our hospital, the patient was referred.

When the laboratory results were examined, HBsAg results of two patients were positive; but antiHBcIgG positivity was accompanying and these patients had chronic hepatitis B prior to suspected contact. Therefore, there was no diagnosis of acute hepatitis B or hepatitis C. Nine $(15 \%)$ patients diagnosed with syphilis had positive VDRL and TPHA (minimum 1/320) tests; for this reason, all were given treatment. White blood cell, CRP, ALT, AST, sedimentation averages were normal at baseline and later (table 3).
Table 2. Symptoms, physical examination findings of the patients and new diagnoses

\begin{tabular}{|c|c|}
\hline Characteristics & Results \\
\hline Complaint & \\
\hline No & $33(\% 53)$ \\
\hline Urethral discharge & $11(\% 18)$ \\
\hline Dysuria & $4(\% 7)$ \\
\hline Discharge and dysuria & $3(\% 5)$ \\
\hline Ulcer & $3(\% 5)$ \\
\hline Ulcer +rash & $2(\% 3)$ \\
\hline Ulcer +discharge+dysuria & $2(\% 3)$ \\
\hline Genital itching & $1(\% 1.5)$ \\
\hline Wart & $1(\% 1.5)$ \\
\hline Swelling in the groin & $1(\% 1.5)$ \\
\hline Urinary incontinence & $1(\% 1.5)$ \\
\hline Physical examination & \\
\hline Normal & $39(\% 63)$ \\
\hline Discharge/redness around the urethra & $14(\% 23)$ \\
\hline Ulcer & $5(\% 8)$ \\
\hline LAP & $2(\% 3)$ \\
\hline Condyloma & $1(\% 1.5)$ \\
\hline Skin rash & $1(\% 1.5)$ \\
\hline New diagnosis (in our polyclinic) & \\
\hline No disease & $28(\% 45.5)$ \\
\hline Urethritis & $16(\% 26.5)$ \\
\hline Syphilis & $7(\% 11)$ \\
\hline HSV infection & $3(\% 5)$ \\
\hline Urethritis + syphilis & $2(\% 3)$ \\
\hline Urethritis + prostatitis & $2(\% 3)$ \\
\hline Urethritis + HSV infection & $1(\% 1.5)$ \\
\hline HIV infection & $1(\% 1.5)$ \\
\hline HPV infection & $1(\% 1.5)$ \\
\hline Tinea cruris & $1(\% 1.5)$ \\
\hline
\end{tabular}

LAP:Lymphadenopathy, HIV: Human immunodeficiency virus, HSV: Herpes simplex virus, HPV: Human papilloma virus

While no pathological result was found in urine cultures performed in patients with urethral complaints, methicillin sensitive coagulase negative Staphylococcus was grown in two patients and methicillin sensitive Staphylococcus aureus was grown in one patient in urethral discharge cultures. Results were considered contamination. Only six patients had pyuria. 
Table 3. Laboratory results at the first admission of patients

\begin{tabular}{|l|c|}
\hline Test & Results \\
\hline HBsAg positivity n(\%) & $2(\% 3)$ \\
AntiHBcIgG positivity n(\%) & $2(\% 3)$ \\
AntiHBs positivity n(\%) & $27(\% 44)$ \\
AntiHCV positivity n(\%) & 0 \\
AntiHIV positivity n(\%) & 0 \\
VDRL positivity n(\%) & $1(\% 1.5)$ \\
TPHA positivity n(\%) & $9(\% 15)$ \\
HSV type 2 IgM positivity n(\%) & $9(\% 15)$ \\
White blood cell average $\left(\mathrm{mm}^{3}\right)$ & $2(\% 3)$ \\
CRP average (mg/L) & $0.27 \pm 0.21$ \\
ALT average (U/L) & $20.82 \pm 10.05$ \\
AST average (U/L) & $20.28 \pm 5.11$ \\
Sed average (mm/hour) & $6.32 \pm 6.05$ \\
Presence of pyuria in CUT* (n,\%) & $6(\% 10)$ \\
\hline
\end{tabular}

"CUT: Complete urine test, AntiHBS positivity: > 10IU / L VDRL:Venereal Disease Research Laboratory, TPHA: Treponema Pallidum Hemagglutination, HSV: Herpes simplex virus, ALT:Alanine aminotransferase AST: Aspartate aminotransferase, CRP: C-reactive protein, Sed: Sedimentation

\section{DISCUSSION}

STDs refers to a variety of clinical syndromes and infections caused by pathogens that can be transmitted through sexual contact. People working in healthcare play a critical role in preventing and treating STDs. STDs prevention and control is based on five main strategies. The first of these is to identify people at risk for this disease group and to provide them with education. Others; to recommend the necessary vaccines before exposure in terms of vaccine-preventable infections, to determine people with asymptomatic or symptomatic STDs, to treat infected people and to evaluate their sexual partners in terms of treatment or counseling (8). Despite all these recommendations, according to the 2018 Centers for Disease Control and Prevention (CDC) data, from 2014 to 2018; there was a significant increase in chlamydia infections by $19 \%$, in gonorrhea by $63 \%$, in congenital syphilis by $185 \%$, in primary and secondary syphilis by $71 \%$ (9). Another important risk indicator in the increasing rate of infection with genital trauma is seroprevalence all over the country. According to the data of the Ministry of Health in our country, while there has been a partial decrease in chlamydia and gonorrhea infections in recent years; the number of syphilis cases, which was 502 in 2015, increased by approximately four times to 2430 in 2018. In addition, in 2018, it was stated that the most frequently diagnosed people with syphilis were male patients between the ages of 30-44 (699 people, 29\%) and 88 syphilis cases over the age of 65 have been reported (10). According to the our country's HIV-AIDS data, the number of HIV-positive people, which was 997 in 2012, rose to 3813 with an approximately four-fold increase in 2019. Until 2019, a total of 26,164 HIV-positive cases, $80.7 \%$ male, $19.3 \%$ female, $15.7 \%$ foreign nationals, have been reported; 1927 of these are AIDS cases. The most common age group of cases is between 25-34. Like all developing countries, in Turkey, the most common way of transmission is sexual contact $(47.8 \%)$. In $68.9 \%$ of the cases known to be transmitted by sexual contact, transmission occurred after heterosexual intercourse (11). In our study, a bisexual patient applied to our outpatient clinic for precautionary measures after homosexual intercourse, and was diagnosed with acute HIV infection. Two of our patients had positive HBsAg results; however, the patients had a diagnosis of chronic hepatitis B before. Acute hepatitis B was not detected in the other patients after six months of follow-up. It was thought that this situation was due to the increasing rate of hepatitis B vaccination in the population. As a matter of fact, antiHBs results of $27(44 \%)$ patients in the study were over $10 \mathrm{IU} / \mathrm{L}$. No anti HCV positivity was found at the end of the six-month follow-up. Four patients were diagnosed with clinical HSV infection and responded to valganciclovir therapy. In two of them HSV IgM had been sent and result was positive; but in the other two of them HSV IgM had not been sent.

In the literature, it was seen in studies with groups where one of the partners was HIV positive and the other negative; continuous use of condoms during sexual contact can reduce the risk of transmission by $60 \%$ (12). In fact, there are studies suggesting that, even occasional condom use reduces the risk of transmission in sexual intercourse with high-risk partners for HIV (13). Some studies have been shown that; one fourth of men, half of women can have urethral gonorrhea infection without symptoms and $90 \%$ of men and $70-95 \%$ of women can have chlamydia infection without symptoms (14-16). It is important to use condoms during intercourse, because of that partners can have STDs without symptoms. The rate of using condoms in our patients were quite low (four patients, 7\%). It was noteworthy that, only two of the 19 patients who had intercourse with sex worker used a condom; the other 17 patients did not use condoms and 14 of these people had at least one diagnosis of STDs (12 urethritis, one syphilis, one HSV infection). In addition, it was observed that, acute phase reactants were low in the initial and subsequent six-month examinations of the patients included in the study, which reminded us that we should not forget that acute phase reactants may be negative in STDs, and that we should continue the investigation in line with the complaints of the patients. People with more than one partner, people with previous STDs, and people living in a region with high prevalence should be evaluated in the increased risk category for all STDs. Risk assessment includes that; counseling, antimicrobial prophylaxis and preventive measures such as vaccination (8). It was observed that, 21 of our patients (34\%) had two or more partners. However, none had previously received a counseling or vaccination recommendation.

Since only adult patients are taken care of in our outpatient clinic; patients over the age of 18 were included to our study. However, there are studies showing that STDs are also seen quite frequently in the adolescent group. For example, in a study the presence of 
at least one of chlamydia, gonorrhea, HSV type 2 or HPV infections in $24 \%$ of patients between the ages of 14-19 has been proven in the laboratory environment (17). While approximately 19 million people are diagnosed with STDs in a year in the United States of America; half of them are between the ages of 15-24 (18). In our study, 21 patients $(34 \%)$ were younger than 25 years old; it is noteworthy that 10 patients $(16 \%)$ are over the age of 50 . In the United States of America (USA), STDs are the most common infectious diseases. Although the infection rate seems less than it is (in the USA), so it is estimated that there are about 20 million new cases every year, due to the low rate of disease reporting, underreporting and the fact that most of this group diseases asymptomatic. Therefore, the estimated annual cost rate is $\$ 16$ billion (19).

In our country, in some studies on the knowledge level of young university students; especially in non-health departments, the knowledge level about STDs was observed low $(20,21)$. Our study has also shown that; many people did not use condom during intercourse, even with a sex worker partner, for reasons such as not knowing the protection measures or risking.

Limitations: Due to the lack of advanced diagnostic facilities, the cause of urethritis has not been specified.

\section{CONCLUSION}

Our aim in this study; was to draw attention to this group of diseases (STDs), whose prevalence has increased in recent years, is observed to be insufficient in compliance with necessary preventive measures, and whose public knowledge level is thought to be insufficient. Considering that the rate of STDs will increase in the coming years, we think that should be attached importance to as required, should raise awareness the public and trainings should be done frequently.

\section{Acknowledgments}

Due to their contribution, the author would like to thank the employees of Düzce Atatürk State Hospital Center Laboratory employees.

Authors's Contributions: Idea/Concept: D.Y.; Design: D.Y.; Data Collection and/or Processing: D.Y.; Analysis and/or Interpretation: D.Y.; Literature Review: SB; Writing the Article: SB; Critical Review: D.Y.

\section{REFERENCES}

1. Ünal S, Zarakolu P. Sexually transmitted diseases. In: Wilke Topçu A, Söyletir G, Doğanay M, editors. Infectious diseases and microbiology. Istanbul: Nobel Medical Bookstore; 2002. p. 1111-23.

2. Paavonen J, Eggert-Kruse W. Chlamydia trachomatis: impact on human reproduction. Human Reproduction Update. 1999; 5(5): 433-47.

3. World Health Organization. Global incidence and prevalence of selected curable sexually transmitted infections 2008. [Updated: 2012; Cited: 2021January 21 ]. Available from: https://apps.who.int/iris/bitstream/handle/10665/7518 1/9789241503839_eng.pdf;jsessionid=40175AFD44 7C9018E0B60B382CE10687? sequence $=1$
4. Siyez DM, Siyez E. Investigation of university students' knowledge of sexually transmitted diseases. Turkish Journal of Urology. 2009; 35(1): 49-55.

5. Özek B. Sexually transmitted diseases and genital tract infections. In: Fundamentals of family planning. Human resource development foundation. Ankara; 1997.

6. Pirinççi N, Ozan T, Çarkçı S. Current treatment of sexually transmitted viral diseases: Urological approach. Andrology Bulletin. 2016; 18(66): 150-5.

7. Doğan S, Altındağ E. Counseling about sexually transmitted diseases. Clinical Medicine Family Medicine-Current and Scientific Medical Journal. 2017; 9(2): 32-6.

8. Workowski KA, Bolan GA. Sexually transmitted diseases treatment guidelines, 2015. MMWR Recommandations and Reports. 2015; 64(RR-03): 1137.

9. CDC. Sexually transmitted disease surveillance 2018. [Updated: 2018; Cited: 2021 January 21]. Available from: https://www.cdc.gov/std/stats18/default.htm

10. T.C. Ministry of Health General Directorate of Public Health. Syphilis statistics. [Updated: 2019 December 31; Cited: 2021 January 21]. Available from: https://hsgm.saglik.gov.tr/tr/bulasicihastaliklar/sifiliz/sifiliz-liste/sifiliz-istatistik.html

11. T.C. Ministry of Health General Directorate of Public Health. HIV-AIDS statistics. [Updated: 2020 November 30; Cited: 2021 January 21]. Available from: https://hsgm.saglik.gov.tr/tr/bulasicihastaliklar/hiv-aids/hiv-aids-liste/hiv-aidsistatislik.html

12. Davis KR, Weller SC. The effectiveness of condoms in reducing heterosexual transmission of HIV. Family Planning Perspectives. 1999; 31: 272-9.

13. Pinkerton SD, Abramson PR. Occasional condom use and HIV risk reduction. Journal of Acquired Immune Deficiency Syndromes and Human Retrovirology. 1996; 13: 456-60.

14. Wallin J. Gonorrhea in 1972: A 1-year study of patients attending the VD unit in Uppsala. British Journal of Venereal Diseases. 1974; (51): 41-7.

15. Farley TA, Cohen DA, Elkins W. Asymptomatic sexually transmitted diseases: The case for screening. Preventive Medicine. 2003; 36: 502-9.

16. Korenromp EL, Sudaryo MK, de Vlas SJ, Gray RH, Sewankambo NK, Serwadda D, et al. What proportion of episodes of gonorrhoea and chlamydia becomes symptomatic? International Journal of STD \& AIDS. 2002; 13: 91-101.

17. Forhan SE, Gottlieb SL, Stenberg MR, Xu Fujie, Datta SD, McQuillan GM, et al., Prevalence of sexually transmitted infections among female adolescents aged 14 to 19 in the United States. Pediatrics. 2009; 124(6): 1505-12.

18. Weinstock H, Berman S, Cates W Jr. Sexually transmitted diseases among American youth: incidence and prevalence estimates, 2000. Perspectives on Sexual and Reproductive Health. 2004; 36(1): 6-10.

19. Decker CF. Sexually transmitted diseases: An overview. Disease-a-Month. 2016; 62: 258-9. 
20. Yazganoğlu KD, Özarmağan G, Tozeren A, Özgülnar N. Knowledge, behavior and attitudes of university students toward sexually transmitted infections. Turkish Archives of Dermatology and Venereology. 2012; 46(1): 20-5.

21. Demir G, Şahin TK. Knowledge of students of Selçuk University about sexually transmitted infections. Journal of Duzce University Health Sciences Institute. 2014; 4(3): 19-24. 